\title{
Spectral Comparison of Neutron-Irradiated Natural and Enriched Ytterbium Targets for Lu-177 Production
}

\author{
M. Maiyesni ${ }^{1{ }^{*}}$, S. Febriana ${ }^{1}$, I. Kambali ${ }^{2}$ and D. Kurniasih ${ }^{1}$ \\ ${ }^{1}$ Center for Radioisotope and Radiopharmaceutical Technology, National Nuclear Energy Agency, \\ Puspiptek Area Serpong, Tangerang Selatan 15310, Indonesia \\ ${ }^{2}$ Center for Accelerator Science and Technology, National Nuclear Energy Agency, \\ Jl. Babarsari, Yogyakarta 55281, Indonesia
}

\section{ARTICLE INFO}

Article history:

Received 1 February 2019

Received in revised form 29 April 2019

Accepted 13 May 2019

\section{Keywords:}

Enriched ${ }^{176} \mathrm{Yb}$

${ }^{177}$ Lu Radioisotope

Neutron

Natural ytterbium

Radioimmunotherapy

\begin{abstract}
A B S T R A C T
Beta-emitting radioisotope ${ }^{177} \mathrm{Lu}$ has been suggested for radioimmunotherapy, peptide receptor radionuclide therapy, or another radionuclide therapy due to its excellent properties for destroying cancer cells. In this experimental investigation, natural ytterbium $\left({ }^{\text {nat }} \mathrm{Yb}\right)$ and enriched ${ }^{176} \mathrm{Yb}$ targets were irradiated with thermal neutrons at $1.2 \times 10^{14} \mathrm{~cm}^{-2} \mathrm{~s}^{-1}$ neutron flux for 95 hours. Using a high-purity germanium (HPGe) detector-based spectroscopy system, the post-irradiated targets were measured and the produced radioisotopes were identified according to their gamma ray emissions. Experimental results indicated that several radioisotopes such as ${ }^{169} \mathrm{Yb}$ and ${ }^{175} \mathrm{Yb}$ dominate the post-irradiated ${ }^{\text {nat }} \mathrm{Yb}$ target, though a relatively weak intensity of ${ }^{177} \mathrm{Lu}$ was also recorded. In contrast, ${ }^{177} \mathrm{Lu}$ radioisotope dominates the gamma rays observed in the post-irradiated enriched ${ }^{176} \mathrm{Yb}$ target following elution with $\mathrm{HNO}_{3}$ solution. For the first time, evidence is found of ${ }^{175} \mathrm{Yb}$ impurity in the post-neutron-irradiated enriched ${ }^{176} \mathrm{Yb}_{2} \mathrm{O}_{3}$ target as a result of ${ }^{176} \mathrm{Yb}(\mathrm{n}, 2 \mathrm{n}){ }^{175} \mathrm{Yb}$ nuclear reaction. This work recommends future ${ }^{177} \mathrm{Lu}$ radioisotope production using enriched ${ }^{176} \mathrm{Yb}_{2} \mathrm{O}_{3}$ target.
\end{abstract}

(C) 2019 Atom Indonesia. All rights reserved

\section{INTRODUCTION}

Application of nuclear technology for medical purposes has been of increasingly great interest, particularly for cancer studies [1-3]. In nuclear medicine, radioisotope-labeled chemical compounds are employed to image patients' organs to diagnose their diseases [4,5], whereas certain radioisotopes are also used for therapy [6,7]. Radioisotopes can be produced using a nuclear reactor [8] or a cyclotron or other accelerators [9-10], though less-commonlyused laser [11] and plasma focus [12] are also suggested for radioisotope production.

Current research activities on production technology of cyclotron-based diagnostic and therapeutic radioisotopes such as ${ }^{18} \mathrm{~F},{ }^{64} \mathrm{Cu},{ }^{99 \mathrm{~m}} \mathrm{Tc}$, ${ }^{153} \mathrm{Sm},{ }^{211} \mathrm{At}$, and ${ }^{177} \mathrm{Lu}$ have been conducted

${ }^{*}$ Corresponding author

E-mail address: maiyesni@yahoo.com

DOI: https://doi.org/10.17146/aij.2019.930 theoretically and experimentally [13-21]. Apart from cyclotron-based radionuclide production, nuclear reactor-based radioisotope production has also been studied elsewhere, including for production of diagnostic and therapeutic radioisotope such as beta-emitting radioisotopes ${ }^{131} \mathrm{I}$ and ${ }^{153} \mathrm{Sm}[22,23]$. The use of nuclear reactor for radioisotope production is due to its excellent capability in generating high flux neutrons, though cyclotron-based radionuclide production has been more attractive due to its capability in generating no-carrier-added radionuclides [24].

In recent years, cancer treatment has shifted from traditional radiotherapy to advanced targeted radiotherapy or commonly coined as radioimmunotherapy as well as peptide receptor radionuclide therapy (PRRT) which uses radioisotope-labeled antibody to deliver cytotoxic radiation to abnormal cells [25]. One of the emerging radioisotopes used in radioimmunotherapy 
is lutetium-177 $\left({ }^{177} \mathrm{Lu}\right)$ which emits beta particles with a half-life of 6.7 days. This excellent property has made it an excellent radiation source for radioimmunotherapy and PRRT. Previous research highlighted that ${ }^{177} \mathrm{Lu}$-labeled radiopharmaceuticals are probably the best radiopharmaceuticals for treatment of small bone lesions [26]. Another investigation suggested that ${ }^{177} \mathrm{Lu}$ could be produced via thermal neutron captures since it has very high neutron capture cross-section of 2090 barns [27]. Direct production of ${ }^{177} \mathrm{Lu}$ can be performed through ${ }^{176} \mathrm{Lu}(\mathrm{n}, \gamma){ }^{177} \mathrm{Lu}$ reaction, whereas the indirect production can be done via ${ }^{176} \mathrm{Yb}(\mathrm{n}, \gamma){ }^{177} \mathrm{Yb} \rightarrow{ }^{177} \mathrm{Lu}$ reaction. Using an indirect method, Salek and coworkers [28] irradiated enriched ${ }^{176} \mathrm{Yb}$ target in thermal a neutron flux of $5 \times 10^{13} \mathrm{~cm}^{-2} \mathrm{~s}^{-1}$ for 14 days which resulted in high radiochemical purities of ${ }^{177} \mathrm{Lu}(>95 \%)$ at optimized conditions, though further investigation is required especially for different irradiation conditions to confirm the results.

In this work, systematic attempts are carried out to irradiate natural $\mathrm{Yb}\left({ }^{\text {nat }} \mathrm{Yb}\right)$ and enriched ${ }^{176} \mathrm{Yb}$ targets using thermal neutrons generated by the G.A. Siwabessy nuclear reactor in Serpong, South Tangerang, Indonesia. Radioisotopes as a result of the thermal neutron irradiation of both targets are identified and compared from their gamma ray emissions.

\section{EXPERIMENTAL METHODS}

\section{Target irradiation}

The targets of interest in this work were natural ytterbium (III) nitrate pentahydrate ${ }^{\text {nat }} \mathrm{Yb}\left(\mathrm{NO}_{3}\right)_{3} .5 \mathrm{H}_{2} \mathrm{O}(99.999 \%$ purity) in the form of powder purchased from Sigma-Aldrich, USA, and enriched ytterbium oxide ${ }^{176} \mathrm{Yb}_{2} \mathrm{O}_{3}(99.9 \pm 0.1 \%$ enrichment of ${ }^{176} \mathrm{Yb}$ ) in the form of powder purchased from Isoflex, USA. The ${ }^{\text {nat }} \mathrm{Yb}\left(\mathrm{NO}_{3}\right)_{3} .5 \mathrm{H}_{2} \mathrm{O}$ target employed in this work contained ${ }^{168} \mathrm{Yb},{ }^{170} \mathrm{Yb},{ }^{171} \mathrm{Yb},{ }^{172} \mathrm{Yb},{ }^{173} \mathrm{Yb},{ }^{174} \mathrm{Yb}$ and ${ }^{176} \mathrm{Yb}$ as stated in the certificate of analysis. In addition, according to the certificate of analysis, the enriched ${ }^{176} \mathrm{Yb}_{2} \mathrm{O}_{3}$ target contained less than $0.05 \%$ of other $\mathrm{Yb}$ atoms.

A total of $26.8 \mathrm{mg}$ of ${ }^{\text {nat }} \mathrm{Yb}\left(\mathrm{NO}_{3}\right)_{3} .5 \mathrm{H}_{2} \mathrm{O}$ target and $9.4 \mathrm{mg}$ of enriched ${ }^{176} \mathrm{Yb}_{2} \mathrm{O}_{3}$ target were prepared without any chemical treatment prior to thermal neutron irradiation. Each powdery target was placed in separate quartz tubes and then sealed by means of laser welding. Aluminium-based inner and outer capsules were then prepared to house the sealed quartz tubes containing the targets. The same procedure was conducted for both targets. In this experimental investigation, the neutron irradiation was conducted in the central irradiation position of the G.A. Siwabessy nuclear reactor in Serpong, Indonesia. A neutron flux of $1.2 \times 10^{14} \mathrm{~cm}^{-2} \mathrm{~s}^{-1}$ bombarded the targets for 95 hours without any significant power disruption or failure. Note that for easier understanding, the natural ${ }^{\text {nat }} \mathrm{Yb}\left(\mathrm{NO}_{3}\right)_{3} \cdot 5 \mathrm{H}_{2} \mathrm{O}$ target and enriched ${ }^{176} \mathrm{Yb}_{2} \mathrm{O}_{3}$ target are called ${ }^{\text {nat }} \mathrm{Yb}$ and enriched ${ }^{176} \mathrm{Yb}$ targets for short, respectively.

\section{Gamma ray detection and measurement}

Following irradiation of the ${ }^{\text {nat }} \mathrm{Yb}$ and enriched ${ }^{176} \mathrm{Yb}$, the post-irradiated targets were dissolved in $3.5 \mathrm{~mL} \mathrm{HCl}(0.15 \mathrm{M}, 32 \%)$ and then mixed and heated to $200{ }^{\circ} \mathrm{C}$. Afterward, $5 \mathrm{~mL}$ $\mathrm{HCl} 0.15 \mathrm{M}$ were added into the solution until perfectly dissolved. In addition, the post-irradiated ${ }^{\text {nat }} \mathrm{Yb}\left(\mathrm{NO}_{3}\right)_{3} .5 \mathrm{H}_{2} \mathrm{O}$ was directly dissolved in $5 \mathrm{~mL}$ $\mathrm{HCl} 0.15 \mathrm{M}$. Following the chemical treatment, they were measured for their gamma ray emissions using a well-calibrated gamma ray spectroscopy system consisting of a HPGe detector coupled with a multichannel analyzer (MCA). The energy resolution of the spectroscopy system was $2 \mathrm{keV}$ at a gamma energy of $662 \mathrm{keV}$. The radiation measurement was conducted for the bulk samples as well as liquid samples after being eluted with $5 \mathrm{ml}$ of $3.4 \mathrm{~N} \mathrm{HNO}_{3}$ solution. The measurement was performed 5 days after neutron irradiation.

\section{RESULTS AND DISCUSSION}

\section{Gamma spectrum of the bulk targets}

The gamma ray spectra of the bulk ${ }^{\text {nat }} \mathrm{Yb}\left(\mathrm{NO}_{3}\right)_{3}$ and enriched ${ }^{176} \mathrm{Yb}_{2} \mathrm{O}_{3}$ are presented in Fig. 1, which shows significant differences in the energy and intensity of the emitted gamma rays. For the bulk ${ }^{\text {nat }} \mathrm{Yb}$, while the emitted gamma ray intensities are relatively low, there are more radioisotopes identified in the spectrum since ${ }^{\text {nat }} \mathrm{Yb}$ contains several atoms which could become radioactive following neutron irradiation (see Fig. 1 inset).

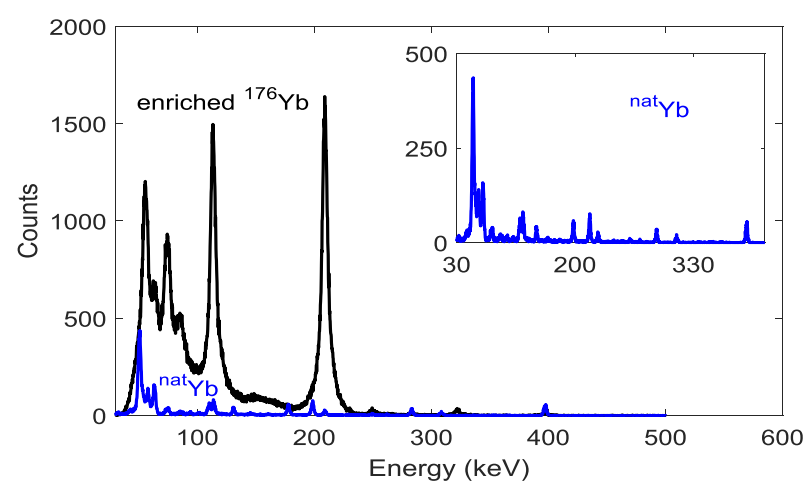

Fig. 1. Gamma ray spectra of the bulk ${ }^{\text {nat }} \mathrm{Yb}\left(\mathrm{NO}_{3}\right)_{3}$ (black line) and enriched ${ }^{176} \mathrm{Yb}_{2} \mathrm{O}_{3}$ (blue line, inset). The $\mathrm{x}$-axis and $\mathrm{y}$-axis in the inset are in the same units as the main figure. 
The corresponding gamma energies and identified radioisotopes are indicated in Table 1 . There are three radioisotopes generated following neutron bombardment of ${ }^{\text {nat }} \mathrm{Yb}$, namely ${ }^{169} \mathrm{Yb}$ as a result of ${ }^{168} \mathrm{Yb}(\mathrm{n}, \gamma){ }^{169} \mathrm{Yb}$ nuclear reaction, ${ }^{175} \mathrm{Yb}$ due to ${ }^{174} \mathrm{Yb}(\mathrm{n}, \gamma){ }^{175} \mathrm{Yb}$ nuclear reaction and ${ }^{177} \mathrm{Lu}$ resulted from ${ }^{176} \mathrm{Yb}(\mathrm{n}, \gamma){ }^{177} \mathrm{Yb} \rightarrow{ }^{177} \mathrm{Lu}$ nuclear reaction. It should be noted that the other $\mathrm{Yb}$ atoms contained in the ${ }^{\text {nat }} \mathrm{Yb}$ target could have also been transmuted into new stable isotopes. For example, ${ }^{170} \mathrm{Yb}$ becomes ${ }^{171} \mathrm{Yb}$ following ${ }^{170} \mathrm{Yb}(\mathrm{n}, \mathrm{X}){ }^{171} \mathrm{Yb}$ reaction, ${ }^{171} \mathrm{Yb}$ becomes ${ }^{172} \mathrm{Yb}$ as a result of ${ }^{171} \mathrm{Yb}(\mathrm{n}, \mathrm{X}){ }^{172} \mathrm{Yb}$ reaction, and ${ }^{173} \mathrm{Yb}$ transmutes into ${ }^{174} \mathrm{Yb}$ due to ${ }^{173} \mathrm{Yb}(\mathrm{n}, \mathrm{X}){ }^{174} \mathrm{Yb}$ reaction. In addition, neutron irradiation of ${ }^{176} \mathrm{Yb}$ atom could result in ${ }^{177} \mathrm{Yb}$ radioisotope, though it would have decayed since its half life is 1.91 hours.

For the bulk enriched ${ }^{176} \mathrm{Yb}_{2} \mathrm{O}_{3}$ target, there is little gamma ray observed in the spectrum which belongs to ${ }^{177} \mathrm{Lu}$ radioisotope following ${ }^{176} \mathrm{Yb}(\mathrm{n}, \gamma){ }^{177} \mathrm{Yb} \rightarrow{ }^{177} \mathrm{Lu}$ nuclear reaction as, again, shown in Table 1. While gamma rays in the energy range between 60 and $400 \mathrm{keV}$ dominate, there also several significant intensities in the energy range below $60 \mathrm{keV}$. The low-energy emissions are presumably due to X-rays emitted by ${ }^{169} \mathrm{Yb},{ }^{175} \mathrm{Yb}$, and ${ }^{177} \mathrm{Lu}[29]$.

Table 1. Radioisotopes generated following neutron irradiation of the bulk ${ }^{\text {nat }} \mathrm{Yb}\left(\mathrm{NO}_{3}\right)_{3}$ and enriched ${ }^{176} \mathrm{Yb}_{2} \mathrm{O}_{3}$ targets.

\begin{tabular}{ccccc}
\hline \hline $\begin{array}{c}\text { Bulk } \\
\text { target }\end{array}$ & $\begin{array}{c}\text { Energy } \\
\text { (keV) }\end{array}$ & $\begin{array}{c}\text { Produced } \\
\text { radioisotope }\end{array}$ & $\begin{array}{c}\text { Half } \\
\text { life }\end{array}$ & $\begin{array}{c}\text { Nuclear } \\
\text { reaction }\end{array}$ \\
\hline${ }^{\text {nat }} \mathrm{Yb}\left(\mathrm{NO}_{3}\right)_{3}$ & 63.12 & ${ }^{169} \mathrm{Yb}$ & 32.02 days & ${ }^{168} \mathrm{Yb}(\mathrm{n}, \gamma){ }^{169} \mathrm{Yb}$ \\
& 109.78 & ${ }^{169} \mathrm{Yb}$ & 32.02 days & ${ }^{168} \mathrm{Yb}(\mathrm{n}, \gamma){ }^{169} \mathrm{Yb}$ \\
& 112.9 & ${ }^{177} \mathrm{Lu}$ & 6.65 days ${ }^{176} \mathrm{Yb}(\mathrm{n}, \gamma){ }^{177} \mathrm{Yb} \rightarrow{ }^{177} \mathrm{Lu}$ \\
& 113.81 & ${ }^{175} \mathrm{Yb}$ & 4.18 days & ${ }^{174} \mathrm{Yb}(\mathrm{n}, \gamma){ }^{175} \mathrm{Yb}$ \\
& 130.52 & ${ }^{169} \mathrm{Yb}$ & 32.02 days & ${ }^{168} \mathrm{Yb}(\mathrm{n}, \gamma){ }^{169} \mathrm{Yb}$ \\
& 144.86 & ${ }^{175} \mathrm{Yb}$ & 4.18 days & ${ }^{174} \mathrm{Yb}(\mathrm{n}, \gamma){ }^{175} \mathrm{Yb}$ \\
& 177.21 & ${ }^{169} \mathrm{Yb}$ & 32.02 days & ${ }^{168} \mathrm{Yb}(\mathrm{n}, \gamma){ }^{169} \mathrm{Yb}$ \\
& 197.96 & ${ }^{169} \mathrm{Yb}$ & 32.02 days & ${ }^{168} \mathrm{Yb}(\mathrm{n}, \gamma){ }^{169} \mathrm{Yb}$ \\
& 208.37 & ${ }^{177} \mathrm{Lu}$ & 6.65 days ${ }^{176} \mathrm{Yb}(\mathrm{n}, \gamma){ }^{177} \mathrm{Yb} \rightarrow{ }^{177} \mathrm{Lu}$ \\
& 249.77 & ${ }^{177} \mathrm{Lu}$ & 6.65 days ${ }^{176} \mathrm{Yb}(\mathrm{n}, \gamma){ }^{177} \mathrm{Yb} \rightarrow{ }^{177} \mathrm{Lu}$ \\
& 251.47 & ${ }^{175} \mathrm{Yb}$ & 4.18 days & ${ }^{174} \mathrm{Yb}(\mathrm{n}, \gamma){ }^{175} \mathrm{Yb}$ \\
& 282.52 & ${ }^{175} \mathrm{Yb}$ & 4.18 days & ${ }^{174} \mathrm{Yb}(\mathrm{n}, \gamma){ }^{175} \mathrm{Yb}$ \\
& 307.74 & ${ }^{169} \mathrm{Yb}$ & 32.02 days & ${ }^{168} \mathrm{Yb}(\mathrm{n}, \gamma){ }^{169} \mathrm{Yb}$ \\
enriched & 396.33 & ${ }^{175} \mathrm{Yb}$ & 4.18 days & ${ }^{174} \mathrm{Yb}(\mathrm{n}, \gamma){ }^{175} \mathrm{Yb}$ \\
${ }^{176} \mathrm{Yb}_{2} \mathrm{O}_{3}$ & 112.9 & ${ }^{177} \mathrm{Lu}$ & 6.65 days ${ }^{176} \mathrm{Yb}(\mathrm{n}, \gamma){ }^{177} \mathrm{Yb} \rightarrow{ }^{177} \mathrm{Lu}$ \\
& 208.3 & ${ }^{177} \mathrm{Lu}$ & 6.65 days ${ }^{176} \mathrm{Yb}(\mathrm{n}, \gamma){ }^{177} \mathrm{Yb} \rightarrow{ }^{177} \mathrm{Lu}$ \\
& 249.7 & ${ }^{177} \mathrm{Lu}$ & 6.65 days ${ }^{176} \mathrm{Yb}(\mathrm{n}, \gamma){ }^{177} \mathrm{Yb} \rightarrow{ }^{177} \mathrm{Lu}$ \\
& 321.3 & ${ }^{177} \mathrm{Lu}$ & 6.65 days ${ }^{176} \mathrm{Yb}(\mathrm{n}, \gamma){ }^{177} \mathrm{Yb} \rightarrow{ }^{177} \mathrm{Lu}$ \\
\hline \multicolumn{7}{c}{}
\end{tabular}

\section{Gamma spectrum of the liquid samples following elution}

Following elution with $\mathrm{HNO}_{3}$ solution, the detected gamma rays for the eluted ${ }^{\text {nat }} \mathrm{Yb}\left(\mathrm{NO}_{3}\right)_{3}$ and enriched ${ }^{176} \mathrm{Yb}_{2} \mathrm{O}_{3}$ are significantly different, particularly the gamma ray spectrum of enriched ${ }^{176} \mathrm{Yb}_{2} \mathrm{O}_{3}$ which shows stronger emissions.
The stronger emissions correspond to the lesser self absorption after elution. Moreover, high energy gamma rays (greater than $300 \mathrm{keV}$ ) can be clearly observed for both eluted samples. For example, in the bulk samples very weak gamma ray intensity is recorded for gamma energy of 396.33 keV (Fig. 1) [30], whereas much stronger intensities are observed for the eluted samples as can be seen in Fig. 2. The recorded gamma rays of enriched ${ }^{176} \mathrm{Yb}_{2} \mathrm{O}_{3}$ following neutron irradiation agrees with previous experimental results reported elsewhere [28].

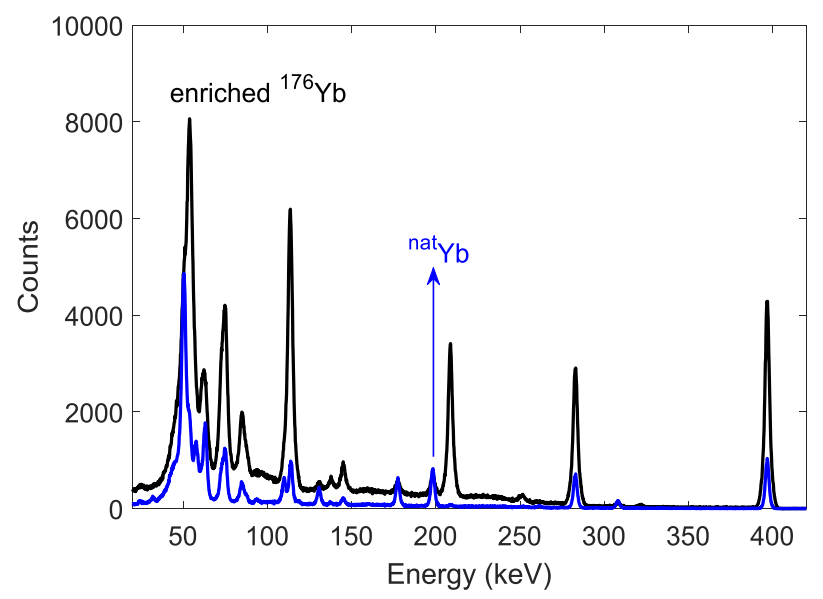

Fig. 2. Gamma ray spectra of the ${ }^{\text {nat }} \mathrm{Yb}\left(\mathrm{NO}_{3}\right)_{3}$ (blue line) and enriched ${ }^{176} \mathrm{Yb}_{2} \mathrm{O}_{3}$ (black line) samples following elution with $\mathrm{HNO}_{3}$ solution.

While the gamma ray spectrum for both ${ }^{\text {nat }} \mathrm{Yb}\left(\mathrm{NO}_{3}\right)_{3}$ and enriched ${ }^{176} \mathrm{Yb}_{2} \mathrm{O}_{3}$ after being eluted with $\mathrm{HNO}_{3}$ are very similar, there is one significant difference in the spectrum, especially the strong emission at $208.37 \mathrm{keV}$ observed in enriched ${ }^{176} \mathrm{Yb}_{2} \mathrm{O}_{3}$ sample, which belongs to ${ }^{177} \mathrm{Lu}$ radioisotope that is hardly seen in ${ }^{\text {nat }} \mathrm{Yb}\left(\mathrm{NO}_{3}\right)_{3}$ sample. In this case, it is clear that enriched ${ }^{176} \mathrm{Yb}$ is a much better target than ${ }^{\text {nat }} \mathrm{Yb}$ target for ${ }^{177} \mathrm{Lu}$ radioisotope production. Details of identified radioisotopes in both ${ }^{\text {nat }} \mathrm{Yb}\left(\mathrm{NO}_{3}\right)_{3}$ and enriched ${ }^{176} \mathrm{Yb}_{2} \mathrm{O}_{3}$ samples after being eluted with $\mathrm{HNO}_{3}$ are shown in Table 2.

One of the most interesting features discovered in the gamma ray spectrum of the enriched ${ }^{176} \mathrm{Yb}_{2} \mathrm{O}_{3}$ sample is the presence of strong emissions at 282.52 and $396.33 \mathrm{keV}$ which correspond to ${ }^{175} \mathrm{Yb}$ signatures.

As already suggested previously, enriched ${ }^{176} \mathrm{Yb}_{2} \mathrm{O}_{3}$ target should be prepared for ${ }^{177} \mathrm{Lu}$ production applicable for radioimmunotherapy, PRRT, or other radionuclide therapies instead of ${ }^{\text {nat }} \mathrm{Yb}$ target. Some main reasons for not using ${ }^{\text {nat }} \mathrm{Yb}$ target are: 
Table 2. Radioisotopes identified from the eluted ${ }^{\text {nat }} \mathrm{Yb}\left(\mathrm{NO}_{3}\right)_{3}$ and enriched ${ }^{176} \mathrm{Yb}_{2} \mathrm{O}_{3}$ targets.

\begin{tabular}{|c|c|c|c|c|}
\hline Bulk target & Energy (keV) & $\begin{array}{c}\text { Produced } \\
\text { radioisotope }\end{array}$ & Half life & Nuclear reaction \\
\hline${ }^{\text {nat }} \mathrm{Yb}\left(\mathrm{NO}_{3}\right)_{3}$ & $\begin{array}{c}63.12 \\
109.78 \\
112.90 \\
113.81 \\
130.52 \\
137.66 \\
144.86 \\
177.21 \\
197.96 \\
208.37 \\
249.77 \\
251.47 \\
282.52[30] \\
307.74 \\
396.33\end{array}$ & $\begin{array}{l}{ }^{169} \mathrm{Yb} \\
{ }^{169} \mathrm{Yb} \\
{ }^{177} \mathrm{Lu} \\
{ }^{175} \mathrm{Yb} \\
{ }^{169} \mathrm{Yb} \\
{ }^{175} \mathrm{Yb} \\
{ }^{175} \mathrm{Yb} \\
{ }^{169} \mathrm{Yb} \\
{ }^{169} \mathrm{Yb} \\
{ }^{177} \mathrm{Lu} \\
{ }^{177} \mathrm{Lu} \\
{ }^{175} \mathrm{Yb} \\
{ }^{175} \mathrm{Yb} \\
{ }^{169} \mathrm{Yb} \\
{ }^{175} \mathrm{Yb}\end{array}$ & $\begin{array}{l}32.02 \text { days } \\
32.02 \text { days } \\
6.65 \text { days } \\
4.18 \text { days } \\
32.02 \text { days } \\
4.18 \text { days } \\
4.18 \text { days } \\
32.02 \text { days } \\
32.02 \text { days } \\
6.65 \text { days } \\
6.65 \text { days } \\
4.18 \text { days } \\
4.18 \text { days } \\
32.02 \text { days } \\
4.18 \text { days }\end{array}$ & $\begin{array}{c}\left.{ }^{168} \mathrm{Yb}(\mathrm{n}, \gamma)\right)^{169} \mathrm{Yb} \\
\left.{ }^{168} \mathrm{Yb}(\mathrm{n}, \gamma)\right)^{169} \mathrm{Yb} \\
{ }^{176} \mathrm{Yb}(\mathrm{n}, \gamma){ }^{177} \mathrm{Yb} \rightarrow{ }^{177} \mathrm{Lu} \\
\left.{ }^{174} \mathrm{Yb}(\mathrm{n}, \gamma)\right)^{175} \mathrm{Yb} \\
{ }^{168} \mathrm{Yb}(\mathrm{n}, \gamma){ }^{169} \mathrm{Yb} \\
\left.{ }^{174} \mathrm{Yb}(\mathrm{n}, \gamma)\right)^{175} \mathrm{Yb} \\
\left.{ }^{174} \mathrm{Yb}(\mathrm{n}, \gamma)\right)^{175} \mathrm{Yb} \\
\left.{ }^{168} \mathrm{Yb}(\mathrm{n}, \gamma)\right)^{169} \mathrm{Yb} \\
\left.{ }^{168} \mathrm{Yb}(\mathrm{n}, \gamma)\right)^{169} \mathrm{Yb} \\
{ }^{176} \mathrm{Yb}(\mathrm{n}, \gamma){ }^{177} \mathrm{Yb} \rightarrow{ }^{177} \mathrm{Lu} \\
{ }^{176} \mathrm{Yb}(\mathrm{n}, \gamma){ }^{177} \mathrm{Yb} \rightarrow{ }^{177} \mathrm{Lu} \\
{ }^{174} \mathrm{Yb}(\mathrm{n}, \gamma){ }^{175} \mathrm{Yb} \\
\left.{ }^{174} \mathrm{Yb}(\mathrm{n}, \gamma)\right)^{175} \mathrm{Yb} \\
{ }^{168} \mathrm{Yb}(\mathrm{n}, \gamma){ }^{169} \mathrm{Yb} \\
{ }^{174} \mathrm{Yb}(\mathrm{n}, \gamma){ }^{175} \mathrm{Yb}\end{array}$ \\
\hline $\begin{array}{l}\text { enriched } \\
{ }^{176} \mathrm{Yb}_{2} \mathrm{O}_{3}\end{array}$ & $\begin{array}{c}112.90 \\
137.66 \\
144.86 \\
208.37 \\
249.77 \\
282.52 \\
321.30 \\
396.33[30]\end{array}$ & $\begin{array}{l}{ }^{177} \mathrm{Lu} \\
{ }^{175} \mathrm{Yb} \\
{ }^{175} \mathrm{Yb} \\
{ }^{177} \mathrm{Lu} \\
{ }^{177} \mathrm{Lu} \\
{ }^{175} \mathrm{Yb} \\
{ }^{177} \mathrm{Lu} \\
{ }^{175} \mathrm{Yb}\end{array}$ & $\begin{array}{l}6.65 \text { days } \\
4.18 \text { days } \\
4.18 \text { days } \\
6.65 \text { days } \\
6.65 \text { days } \\
4.18 \text { days } \\
6.65 \text { days } \\
4.18 \text { days }\end{array}$ & $\begin{array}{l}{ }^{176} \mathrm{Yb}(\mathrm{n}, \gamma){ }^{177} \mathrm{Yb} \rightarrow{ }^{177} \mathrm{Lu} \\
\left.{ }^{176} \mathrm{Yb}(\mathrm{n}, 2 \mathrm{n})\right)^{175} \mathrm{Yb} \\
{ }^{176} \mathrm{Yb}(\mathrm{n}, 2 \mathrm{n})^{175} \mathrm{Yb} \\
{ }^{176} \mathrm{Yb}(\mathrm{n}, \gamma){ }^{177} \mathrm{Yb} \rightarrow{ }^{177} \mathrm{Lu} \\
{ }^{176} \mathrm{Yb}(\mathrm{n}, \gamma){ }^{177} \mathrm{Yb} \rightarrow{ }^{177} \mathrm{Lu} \\
{ }^{176} \mathrm{Yb}(\mathrm{n}, 2 \mathrm{n}){ }^{175} \mathrm{Yb} \\
{ }^{176} \mathrm{Yb}(\mathrm{n}, \gamma){ }^{177} \mathrm{Yb} \rightarrow{ }^{177} \mathrm{Lu} \\
\left.{ }^{176} \mathrm{Yb}(\mathrm{n}, 2 \mathrm{n})\right)^{175} \mathrm{Yb}\end{array}$ \\
\hline
\end{tabular}

(1) The natural abundance of ${ }^{176} \mathrm{Yb}$ is only $12.76 \%$, (2) The ${ }^{176} \mathrm{Yb}(\mathrm{n}, \gamma){ }^{177} \mathrm{Yb}$ nuclear reaction has a low nuclear cross-section (2.4 barns) that results in low ${ }^{177} \mathrm{Lu}$ radioactivity. In contrast, nuclear crosssections for ${ }^{168} \mathrm{Yb}(\mathrm{n}, \gamma){ }^{169} \mathrm{Yb}$ and ${ }^{174} \mathrm{Yb}(\mathrm{n}, \gamma){ }^{175} \mathrm{Yb}$ nuclear reactions are 3470 barns and 65 barns respectively. Therefore, in the post-neutron irradiation ${ }^{\text {nat }} \mathrm{Yb}$ target, ${ }^{169} \mathrm{Yb}$ and ${ }^{175} \mathrm{Yb}$ intensities dominate. Furthermore, ${ }^{177} \mathrm{Lu}$ radioisotope dominates in the neutron irradiated ${ }^{176} \mathrm{Yb}_{2} \mathrm{O}_{3}$ target, though ${ }^{175} \mathrm{Yb}$ impurity is also present due to ${ }^{176} \mathrm{Yb}(\mathrm{n}, 2 \mathrm{n}){ }^{175} \mathrm{Yb}$ nuclear reaction, (3) ${ }^{177} \mathrm{Yb}$ is very difficult to separate from the impurities since they have the same chemical properties.

\section{CONCLUSION}

Neutron irradiation of ${ }^{\text {nat }} \mathrm{Yb}\left(\mathrm{NO}_{3}\right)_{3}$ and enriched ${ }^{176} \mathrm{Yb}_{2} \mathrm{O}_{3}$ targets has been carried out using the G.A Siwabessy nuclear reactor in Serpong, Indonesia to compare the gamma ray spectrum and identified radioisotopes present in each target. Experimental results indicate that for ${ }^{\text {nat }} \mathrm{Yb}\left(\mathrm{NO}_{3}\right)_{3}$ target, two radioisotopes, ${ }^{169} \mathrm{Yb}$ and ${ }^{175} \mathrm{Yb}$, are generated and dominate the post-neutron irradiated ${ }^{\text {nat }} \mathrm{Yb}$ target, whereas relatively weak intensity of ${ }^{177} \mathrm{Lu}$ can also be produced. However, in the postneutron irradiated enriched ${ }^{176} \mathrm{Yb}_{2} \mathrm{O}_{3}$ target, ${ }^{177} \mathrm{Lu}$ radioisotope dominates, though ${ }^{175} \mathrm{Yb}$ impurity is also present due to ${ }^{176} \mathrm{Yb}(\mathrm{n}, 2 \mathrm{n}){ }^{175} \mathrm{Yb}$ nuclear reaction. This work clearly confirms that ${ }^{177} \mathrm{Lu}$ production results in much better radioactivity yield when performed using enriched ${ }^{176} \mathrm{Yb}_{2} \mathrm{O}_{3}$ target. In addition, future works should concentrate on ${ }^{177} \mathrm{Yb}-{ }^{177} \mathrm{Lu}$ separation technique.

\section{ACKNOWLEDGMENT}

The authors would like to acknowledge the funding from The Indonesian National Nuclear Energy Agency (BATAN). Technical assistance from and discussion with several staff of the Center for Radioisotope and Radiopharmaceutical Technology, BATAN, are also gratefully acknowledged.

\section{REFERENCES}

1. L. Deilami-nezhad, L. Moghaddam-Banaem, M. Sadeghi et al., Appl. Radiat. Isot. 118 (2016) 124.

2. L.E.L. Hendriks, B.C.M Hermans, M.H.J van den Beuken-van Everdingen et al., Review J. Thorac. Oncol. 11 (2016) 155.

3. L. Marcu, E. Bezak and B.J. Allen, Critical Reviews in Oncology/Hematology $\mathbf{1 2 3}$ (2018) 7.

4. I. Sonni, L. Baratto L and A. Lagaru, PET Clinics 12 (2017) 159.

5. F. Kataoka, N. Susumu, W. Yamagami et al., , Gynecologic Oncology 140 (2016) 400. 
6. J.M. Van Dodewaard-de Jong, D.E. OpreaLager DE, L. Hooft et al,. A Systematic Review European Urology 70 (2016) 416.

7. E. Evans and J. Staffurth, J. Surgery (Oxford) 36 (2018) 111.

8. I.M. Cohen, A. Robles, P. Mendoza et al., Appl. Radiat. Isot. 135 (2018) 207.

9. M. Gumiela, Nucl. Med. Biol. 58 (2018) 33.

10. V.N. Starovoitova, L. Tchelidze and D.P. Wells, Appl. Radiat. Isot. 85 (2014) 39.

11. S. Kimura and A. Bonasera, Nucl. Instrum. Meth. Phys. Res. A 637 (2011) 164.

12. M.V. Roshan, S. Razaghi, F. Asghari et al., Phys. Lett. A 378 (2014) 2168.

13. I. Kambali, T. Heryanto, R. Rajiman et al., Atom Indonesia 37 (2011) 5.

14. I. Kambali, H. Suryanto and Parwanto, Phys. Eng. Sci. Med. 39 (2016) 403.

15. I. Kambali, Parwanto, H. Suryanto et al., Physics Research International 2017 (2017) 1.

16. I. Kambali, Atom Indonesia 3 (20.14) 129.

17. I. Kambali, Makara J. Sci. 21 (2017) 125. (in Indonesia)

18. I. Kambali, Journal of Physics: Conference Series 1116 (2018) 032013.

19. I. Kambali, Journal of Physics: Conference Series 1120 (2018) 012010.
20. I. Kambali, Journal of Physics: Conference Series 1120 (2018) 012011.

21. I. Kambali, Journal of Physics: Conference Series 1153 (2019) 012106.

22. B. El Bakkari, B. Nacir, T. El Bardouni et al., Ann. Nucl. Energy 78 (2015) 140.

23. Sh. Forughi, S. Hamidi, H. Khalafi et al., Ann. Nucl. Energy 57 (2013) 16.

24. M. Sharifian, M. Sadeghi, B. Alirezapour et al., Appl. Radiat. Isot. 22 (2017) 136.

25. J.M. Redman, E.M. Hill, D. Al Deghaither et al., Mol. Immunol. 67 (2015) 28.

26. F.D-C.G. Liberal, A.A.S. Tavares and J.M-R.S. Tavares, Appl. Radiat. Isot. 110 (2016) 87.

27. A. Dash, M.R.A. Pillai and F.F. Knapp, Nucl. Med. Mol. Imaging 49 (2015) 85.

28. N. Salek, S.S. Arani, A.B. Samani et al., Phys. Eng. Sci. Med. 41 (2017) 69.

29. Anonymous, X-Ray Transition Energies Database, National Institute of Standard and Technology, https://physics.nist.gov/PhysRefData/XrayTrans/Html/search.html (Retrieved in April 2019)

30. N.P. Dikiy, A.N. Dovbnya, N.V. Krasnoselsky et al., Problems of Atomic Science and Technology 112 (2017) 130. 